нізації усіх сфер життя суспільства, зокрема і правового, оновленню конструктивного механізму захисту прав та свобод людини і громадянина, що є головною метою конституціоналізації правового порядку.

Ключові слова: права людини, правова реформа, конституційна реформа, конституціоналізація, правовий порядок.

Резюме

Пархоменко Н.Н., Подорожна Т.С. Правовая реформа как инструмент конституционализации правового порядка.

В статье исследованы проблемы конституционализации правового порядка сквозь призму правовой реформы. Указано, что для современной ситуации в правовой сфере (состояния конституционализации права) характерны такие отрицательные черты: отсутствие рационально обоснованной правовой политики, системности решений государственной власти; оптимальных экономических и политических условий для развития правовой системы в целом и отдельных ее элементов; низкий уровень правосознания субъектов права и высокий уровень правового нигилизма; консерватизм и инертность отдельных субъектов правовой системы. Все эти обстоятельства выступают серьезным тормозом правового порядка. Реформирование тесно связано с изменением власти, политической системы, политики государства, идеологии, изменением политического курса.

Сделан вывод, согласно которому при осуществлении правовой реформы важно неуклонно придерживаться принципов верховенства права, юридической определенности и сформированного в правовых позициях Европейского суда по правам человека принципа пропорциональности. Указанные правовые механизмы будут оказывать содействие более эффективному конституционному развитию Украины, усовершенствованию и гармонизации всех сфер жизни общества, в частности и правового, обновлению конструктивного механизма защиты прав и свобод человека и гражданина, что является главной целью конституционализации правового порядка.

Ключевые слова: права человека, правовая реформа, конституционная реформа, конституционализация, правовой порядок.

\title{
Summary
}

Nataliia Parkhomenko, Tetiana Podorozhna. Legal reform as an instrument of constitutionalization of the legal order.

The article examines the problems of constitutionalization of the legal order in the light of legal reform. It is noted that the current situation in the legal sphere (in the state of constitutionalization of law) is characterized by the following negative features: the lack of rational legal policy and of systematic decisions of public authorities; the lack of optimal economic and political conditions for the development of the legal system as a whole and its individual elements; the low level of legal awareness of subjects of law and the high level of legal nihilism; conservatism and inertness of individual subjects of the legal system. All these circumstances are a serious obstacle to the legal order. Reforming is closely related to the change of power, political system, state policy, ideology, political course. In such situations, there is a need for systematic improvement of existing legislation. And it is necessary to make amendments not to separate laws, but to the whole legal field which needs systematic updating. It is emphasized that legal reform should be divided into three main areas: constitutional, legislative and judicial. These are, first of all, the reform of public administration, administrative and territorial reform, judicial and legal reform, the reform of criminal justice, and the reform of local self-government in Ukraine. All these areas are interconnected. At the same time, taking into account the fundamental importance of constitutional law (in relation to other branches of law), there is a need to substantiate the possibility of implementing constitutional principles into the fields of current legislation in order to further constitutionalize the legal order. In view of this, an important step for the legal enforcement of reforms is the constitutional reform, the implementation of which is part of the problem of the development of statehood, improving the legal system of Ukraine.

It is concluded that in the implementation of legal reform it is important to strictly adhere to the principles of the rule of law, of legal certainty, and of proportionality, with the latter formed in the legal positions of the European Court of Human Rights. These legal mechanisms will contribute to more effective constitutional development of Ukraine, improvement and harmonization of all spheres of public life, including legal one, renewal, constructive mechanism for protection of human and civil rights and freedoms, which is the main goal of constitutionalization of the legal order.

Key words: human rights, legal reform, constitutional reform, constitutionalization, legal order.

DOI: $10.36695 / 2219-5521.2 .2020 .04$

UDC 378.09

ANATOLII KOSTRUBA

Anatolii Volodymyrovych Kostruba, Dr. hab. in Law, Professor, Professor of the Juridical Institute of Vasyl Stefanyk Precarpathian National University*

ORCID: 0000-0001-9542-0929

\section{PEDAGOGICAL MODEL OF THE FORMATION OF PROFESSIONAL COMPETENCES OF LAWYERS: UKRAINIAN REALITY}

Problem definition. The main vector of the development of higher legal education in Ukraine is determined by the general orientation of the national higher education towards entry into the pan-European and global educational space, harmonization of national and international standards of higher education in the context of the Bologna process. On the other hand, rapid development of information technologies has led to the global computerization of society. As a result of this phenomenon in the field of education, the developed data processing environment, mo-

(C) Anatolii Kostruba, 2020

* Анатолій Володимирович Коструба, доктор юридичних наук, професор, професор Навчально-наукового юридичного інституту Прикарпатського національного університету імені Василя Стефаника 
dular assembly of information systems (combination of different types of architectural solutions within the same complex) were formed. Consequently, the process of knowledge accumulation for the development of professional competence skills gradually changes the form of implementation. Well-known goals of higher education that are discovered in such elements as knowledge, understanding, forms of their gaining are subject to changes. Unfortunately, such changes do not always have a positive educational trajectory. It must be admitted that educational institutions are no longer the primary educational resource. Those basic goals that are pursued by higher education do not receive appropriate positive response from society. High knowledge level without skills of their application is a major factor in the professional deformation of a graduate of the higher education institution. This problem is clearly visible in the field of higher legal education. Public statistical sources of the State Employment Service of Ukraine indicate that persons with higher legal education take one of the leading places $(26 \%)$ among the total number of unemployed persons with higher education who have not been able to find their first job ${ }^{1}$. At the beginning of 2019, the Ministry of Justice of Ukraine has proposed the Concept of legal education reform developed together with the Ministry of Education and Science of Ukraine for public discussion. The main issue is the inconsistency between the content of legal education and quality of training in law schools and the modern requirements of the labor market, challenges facing modern democratic society, global development trends and tasks of professional activity of lawyers in various fields. The foregoing calls for the change in the educational paradigm one of the components of which, in our opinion, should be the transition to educational goals of another qualitative type in the cognitive field, including the development of applied professional legal skills, development of critical thinking, etc.

Analysis of recent research and publications. Current issues of higher education pedagogy development are the subject of fundamental researches of representatives of pedagogical science. Back in the early 1990s, there were some changes in pedagogical science in Ukraine: research institutes of pedagogy and psychology of vocational education, higher education were established; periodicals devoted to the problems of organizing the educational process in higher education were founded. This is evidenced by scientific works of such famous scientists as: V. Andrushchenko, M. Holovatyi, M. Yevtukh, V. Zhuravskyi, V. Kremin, V. Kovalenko, I. Moroz, S. Mayboroda². Unfortunately, there is a lack of narrow-subject studies in this field. Pedagogical problems of forming a model of lawyers with their readiness for social interaction have not been given much attention.

It should be noted that among legal scholars there is also no interest in the development of legal pedagogy as a direction in higher education pedagogy, the subject of which is the didactic features of the formation of professional competences exactly for lawyers. By the Decree of the President of Ukraine "On the Legal Reform Commission" $\mathrm{d} / \mathrm{d}$ June 21, 2019 № 421/20193 the appropriate Commission was formed, within which the working group on the development of legal education operates, however, unfortunately, no fundamental theoretical or substantive practical steps have been taken to address the issues identified. Despite the fact that the working group includes representatives of legal science of leading higher education institutions, initiatives regarding the process of legal education reform are taken solely by the Ministry of Education and Science of Ukraine and the Ministry of Justice of Ukraine.

Pedagogical scientists, in particular scientists of the theory and methodology of education and upbringing (by fields and level of education), paid attention to the formation of professional competence of students of law schools on a piecemeal basis. The methodological basis of such research is comprised of the provisions of hermeneutical approach in pedagogy and the idea of synergetic in the humanitarian paradigm of scientific knowledge, provisions of the activity approach in education, theoretical development of competence approach in higher vocational education.

The abovementioned requires the actualization of the issue of modernization of educational processes in the direction of the formation of competence-oriented training and education of professional lawyer in the light of his/her dialog-discussion and linguistic-intensive professional activity, and creation of an appropriate model of professional training of the lawyer.

Purpose statement. The purpose of the article is to develop an algorithm of professional training of the future lawyer including the production of a model for the formation of professional competences of the lawyer, which shall be based on the organic unity of theoretical, practical, psychophysical training, which in turn will provide the level of professional socialization.

Statement of basic materials. Our research into the process of the formation of professional competences of future lawyers shows that at present the fragmentation approach prevails in the teaching practice of law students. In the process of training law students the focus is on the content of professional discipline-oriented knowledge. Meanwhile, the reasons for failures in professional training problem solving lie in the development of their practical skills. This is due to the fact that this aspect of the professional training of law students is not specifically emphasized as a special educational goal.

The analysis of theoretical and methodological researches and practice of work with students of higher education institutions shows that the process of learning professional practical skills often stops at the level of unconscious incompetence or, at best, conscious incompetence. Therefore, the agenda is focused on the necessity for improvement of the pedagogical model of the process of formation of the legal competences of the lawyer, in particular, the component of its substantive and didactic segments.

The use value of the proposed approach to the process of the formation of professional competences of the lawyer is that under the conditions of improvement of the above segments, it is possible, firstly, to avoid overloading the curriculum with unnecessary courses, and secondly, to provide high-quality professionally necessary differentiated training of law students during the entire period of study.

Thus, the implementation of such a private methodological system achieves the integrity of the whole system of professional training of lawyers, which in turn will ensure the integrity and consistency of legal knowledge and linguistic skills, their practical implementation, and will contribute to the formation of a level of conscious competence of law students. 
Opinions. The concept of competence is defined in the Law of Ukraine "On Higher Education"4 as a dynamic combination of knowledge, abilities and practical skills, ways of thinking, professional, ideological and civic qualities, moral and ethical values, which determines the ability of a person to successfully pursue professional and further educational activities and is the result of study at a certain level of higher education.

Therefore, competence is an integration category that assumes the unity of legal knowledge and speech skills of the particular individual the structural component of which is comprised of the following three components: 1. professional and informative (theoretical) components, which includes theoretical knowledge that ensures the accuracy of the legal and substantive content of professional activity; 2. professional and activity (practical) component, which includes professionally relevant skills tested in educational activities and mastered by students as the most effective ones; 3. professional and personal component, which includes professional and personal behavior that determine the position and orientation of the student as an individual and process owner towards achieving a certain level of language professionalism 5 .

Today the concept of "Key competences" is being actively discussed in the scientific environment. This concept includes the following components: social competence as the ability to take responsibility in professional decision making; communicative competence, that is, communication technologies mastering; cognitive competence as the ability to independently gain new knowledge and skills, to realize personal potential; social and informational competence - information technology possession, and special competence, that is, readiness to perform professional functions ${ }^{6}$.

It should be noted that all five of these key competences are directly related to the formation of the lawyer's skills of professional interaction in the social environment. Moreover, communicative competence is the objective result of the integration of cognitive competence, since professional speech implies mental activity and special competence, as a certain amount of special professionally relevant linguistic knowledge. In turn, special competence integrates social and informative one. It's worth mentioning that social competence is the result of the consolidation of all others (communicative, cognitive, social and informational, special). That is not by chance, since the social responsibility of professional lawyer implies both communication technologies mastering, and the ability to selfimprove intellectual potential.

Modern legal psychology has no complete agreement of opinion on the structure of legal activity, however, most researchers identify common, all-specialty structural components of professional activity of lawyers: gnostic component (research or cognitive); organizational component (contacts with participants of certain legal actions); structural component (generalization, analysis of legal facts, argumentation and hypothesis generation); certification component (well-developed written speech); educational component (ability to influence a person); communicative component (professional monologue, dialogue) ${ }^{7}$.

Structural components of professional competence of the lawyer are interrelated, and each of them serves as an integrative function with respect to all the components of professional activity of the lawyer of any specialty.

Such "integrity" in the substantive content of competences as a whole implies a systematic combination of multidisciplinary knowledge, abilities and practical skills which makes it possible to prepare professional lawyer. The formula for this combination is quite diverse. The key in this formula is the need to synthesize the formation of key competences of the future lawyer. Thus, relatively isolated formation of the abovementioned key competences of the lawyer will result in a defect in his/her professional trajectory, which, in turn, will make it impossible for $\mathrm{him} /$ her to socially interact in professional environment.

In other words, according to modern scientific approaches to the realization of the person as the lawyer, the process of the formation of his/her personal identity must take place under the conditions of dynamic combination of differentiated elements of different competence or integration of key competences into the image of the professional lawyer.

In this case, such a synergistic combination of dynamic elements of different competences should occur with such a static segment as the corresponding elements of special competence. The specified method provides professional orientation of the law student.

At the same time, formation of the communicative competence can be achieved by means of combination of disciplines of the linguistic and legal cycles with clear structuring of professionally relevant communicative knowledge selected for the educational process. In this case, teaching the disciplines of the language cycle is a way of gaining knowledge that is a component of communicative competence. In turn, the disciplines of the legal cycle ensure formation of the special competence of the lawyer (the ability to perform professional functions).

Professionally oriented communication training of the lawyer involves, above all, knowledge of the specifics of communication in a particular area, peculiarities of the implementation of various types of legal activity due to the nature of the profession.

Another example of the integrated approach to the formation of professional competences is the development of legal cases management skills as a result of combining elements of cognitive competence and special competence.

Thus, professional competence of the future lawyer is based on the knowledge of the typology of professional and legal tasks, on the one hand, and includes their analysis, professional evaluation and application, on the other hand.

Defining the purpose of the professional training of lawyers is a part of an appropriate pedagogical model that can be defined as target segment of the pedagogical model of the process of formation of the lawyer. Activity approach as a set of particular educational technologies or techniques is the core of the professional training of lawyers. It is a methodological basis upon which the different training systems with their specific technologies, techniques and theoretical features are built. In this way, we shift away from the method of knowledge translation and their passive gaining enabling the achievement of educational goals that meet the needs of society and the state. 
Within the target segment - achievement of the goal - formation of future lawyers' readiness for professional interaction based on the basic principles of scientific approaches and principles of organization of educational process ${ }^{8}$.

The second segment of the pedagogical model is the resource provision for professional training of the lawyer. This module provides for the formation and implementation of a cycle of disciplines that provide the achievement of educational goals set within the first segment of the pedagogical model. This segment solidifies a meaningful content of the pedagogical process of formation of the future lawyer with pedagogical material concerning the professional competences of the lawyer. In our opinion, such cycle substantially includes humanities, thematic legal disciplines and special-purpose disciplines aimed at the extension of professional training. At the same time, the proportion in the distribution of time of the educational process should invariably increase towards the special-purpose disciplines against humanities cycle, which corresponds to the competence-oriented approach of the modern higher education.

Today, it must be admitted that large part of the disciplines that Ukrainian law students learn have nothing to do with law and future practice of law. It is important to provide basic and elective courses which will save time for concentrating attention on mastering the thematic legal disciplines and special-purpose disciplines aimed at the extension of professional training

By providing a meaningful component in developing the competencies of a future lawyer, this module forms accordingly meaningful segment of the pedagogical model of the process of formation of the lawyer.

The third element of the pedagogical model of the process of the formation of future lawyer is didactic segment.

This block includes the stages of organization of the educational process, blocks of theoretical and practical training of future specialists, teaching methods. This segment is comprised of the forms of organization of the educational process as a way of organizing, constructing and holding classes in which the content of educational work, didactic tasks and teaching methods are implemented. Depending on the purpose forms of organization of educational process are divided into lectures, practical classes, seminars, laboratory sessions, laboratory practical works; students' individual work; scientific expeditions, excursions, educational conferences; consultations, etc.

Roman Melnyk points to the issues of unnecessary theorization of educational process due to the excessive academic loads in the form of lectures 9 . According to the scientist, in this context the most telling example is the approach of the German authors of law literature, who pay great attention not only to the compilation of practical exercises, which are solved by German law students in the course of practice, preparation for exams, but also to the development of methods of legal analysis of relevant cases. This makes it possible to achieve the uniformity of legal thinking, to develop uniform approaches to the law enforcement practice in general and case law in particular.

Currently, innovative processes in the field of higher legal education result in the introduction of such new forms of education as the legal clinic. Its purpose is to prepare law graduates for their future practical activity.

Back in the 19th century, law faculty in different countries (Germany, Russia, etc.) faced the problem of the gap between the level of knowledge, skills and qualities of graduates and the requirements of employers for young lawyers' qualification. Students studied serious scientific disciplines, and the experience was expected to be purchased later after graduation.

In the countries of Anglo-Saxon legal tradition, the training of lawyers was conducted exclusively in the form of individual mentoring: the young man became the assistant of an experienced lawyer, at first he carried out small tasks, watched the work of the master and step by step was allowed to a more responsible independent activity ${ }^{10}$.

In the late XIX and early XX centuries, scientists and practitioners in Russia actively discussed the issue of "Organization of educational process at Law Departments". In particular, in 1901 professor Liublinskyi O. I. wrote the article "On Legal Clinics" for the Journal of the Ministry of Justice where he stated that the establishment of legal clinics in Russia is particularly desirable in view of the overly theoretical nature of teaching at Law Departments, the diversity and number of courts with a specific competence inherent in each of them, as well as the poverty and illiteracy of the majority of the population ${ }^{11}$. In the 1930s, Professor Mayer organized a law clinic at Kazan University ${ }^{12}$.

At present, in Ukraine there are over 130 legal clinics. Similar forms of students' education are implemented at the Vasyl Stefanyk Precarpathian National University, Yaroslav Mudryi National Law University and other leading educational institutions, usually it starts in 3-4th academic year, sometimes in 1st year.

Current system of legal education in Ukraine is based on the formation of students' theoretical knowledge, which, of course, provides a certain level of quality of students (future specialists) training. In traditional academic studies, most of the curriculum includes lectures and seminars. In the study of disciplines emphasis is placed primarily on the subject, content and specificity of the studied discipline. However, this approach does not fully allow students to have an understanding of cross-curricular links within the specialty as a whole. In addition, traditional teaching is based on explanatory, illustrative and reproductive methods. Its essence is reduced to the procession of transferring ready, known and "final" knowledge to the student (commenting on the rules of law, explanation of scientific definitions, etc.). The result is the students' passive attitude to learning.

Legal clinic training is based on new technologies: at each stage of study and work in the clinic the student should not only keep in mind the information he/she traditionally receives in classrooms, at academic sessions, but also try to apply it to the realities of legal practice through appropriate interactive teaching methods: role-playing games, case analysis, brainstorming, small group work.

To generate the system of professional training of lawyers, it is necessary to determine the scope of the professional training of law students. It is known that in the complex and multifaceted professional activity of the lawyer the basic operations are the following: 1) fact finding; 2) legal evaluation of factual data; 3) establishing legal behaviors, that is, correlation of a life situation with a specific legal norm, the call to ensure its effectiveness; 4) procedural activities to solve the case; 5) preparation and execution of the legal document. All these areas of legal activity have determined applied orientation in the future lawyer's professional training system. 
Finally, the evaluation and productive segment of the pedagogical model of the process of preparation of the lawyer constitutes its last element. It includes levels of preparedness of future lawyers for professional interaction, defined on the basis of criteria and indicators developed, and methodological complex of pedagogical influence which is aimed at correction of the obtained results in the process of preparation ${ }^{13}$.

The evaluation and performance component of the proposed model is designed to meet current labor market requirements for the training of law professionals. Control during the formation of the legal competences of the lawyer should meet the goals and objectives of legal education, have the adequacy and adaptability of control methods, objectivity of the relevant results.

An important step in the training of future lawyers is not only the formation of professional skills, but also assessment of the level of their development. This shall be achieved through such techniques as test control and case studies. The principal innovation in this area is the unified professional entrance examination as a form of entrance test in law and general educational legal competences for admission to study for the Master degree on the basis of the higher education degree (Specialist degree), which involves the use of organizational and technological processes of external independent evaluation for entrants with a specialization in 081 "Law" and 082 "International Law", and such a form of assessment of the level of special (professional, subject) competences of students defined by the standards of higher education and sufficient for effective performance of professional activity by occupation as the only state qualification examination.

${ }^{1}$ Koziakov S.Iu., Lylyk S.V., Lylyk I.V., Pyrohova D.I., Krasnovskyi O.V. (2015) Analytical report on the results of the project "Public participation in the formation of the framework of qualifications of the legal profession by analyzing knowledge, the list of skills and competences that law graduate needs to possess to meet the demands of today's labor market. Kyiv: Ukrainian Marketing Association.

2 Andreychuk S. (2006) State administration of higher education in the context of the Bologna Declaration. Actual problems of public administration reform in Ukraine, Lviv, 16-01; Zhuravskyi V.S. (2003). Higher education as a factor of state formation and culture in Ukraine. Ukraine: In Jure; Mayboroda S. V. (2002) Higher education of Ukraine under the conditions of integration into the world educational space. State administration in the context of integration into the European Union, Kyiv, 29-05; Kremen V.H., Nikolayenko S.M., Stepko M.F. K. (2005). Higher education in Ukraine. Kyiv: Osvita.

3 Ukaz pro Komisiiu z pytan pravovoi reform 2019 (Prezydent Ukrainy). [Decree about the Legal Reform Commission 2019 (President of Ukraine)]. Ofitsiinyi visnyk Prezydenta Ukrainy. [Official Bulletin of the President of Ukraine], 15, 374 [in Ukrainian].

${ }^{4}$ Zakon pro vyshchu osvitu 2014 (Verkhovna Rada Ukrayiny). [Law about Higher Education 2014 (Verkhovna Rada of Ukraine)]. Ofitsiynyy sayt Verkhovnoyi Rady Ukrayiny. [The official website of the Verkhovna Rada of Ukraine]. Retrieved from https://zakon.rada. gov.ua/laws/show/1556-18 [in Ukrainian]. (2018, April, 04).

5 Kosianova O.M. (2006) More on the formation of professional communicative competence of students of legal specialties. Problems of speech culture in the modern communication space, Nizhny Tagil, 16-04.

6 Zimniaia I.A. (2003) Key competences are the new paradigm of education results. Higher education today, 5, 35-41.

${ }^{7}$ Kartashov V.N. (1998) Legal practice in the legal system of society. In Marchenko M.N. (Ed), Basic theory of the state and law (pp. 130-176). Moscow: Zertsalo; Shykhantsov H.H. (2000) Legal psychology. Moscow: Iurist; Matuzov N.I. (2002) Legal practice. In Malko A.V. (Ed), Theory of the state and law (pp. 230-245). Moscow: Jurist.

${ }^{8}$ Bratkova O.I. (2018) Scientific approaches in training future lawyers for professional interaction. Bulletin of Zhytomyr Ivan Franko State University. Pedagogical Sciences, 4(95), 20-25.

${ }^{9}$ Melnyk, R. (2013) Ukrainian legal education as it is: problems and solutions. Accounting, analysis and audit: problems of theory, methodology, organization, 1, 176-180.

10 Honcharenko V.O. (2004) Legal Clinic: History and Definitions. Practical experience of "legal clinics" in Ukraine, 1, 3-5.

11 On "legal clinics" (1901). Journal of the Ministry of Justice, 1-2, 175-181.

12 Honcharenko V.O. (2004) Legal Clinic: History and Definitions. Practical experience of "legal clinics" in Ukraine, 1, 3-5.

13 Bratkova O.I. (2019) Structural and functional model of the process of the formation of future lawyers' readiness for professional interaction. Teacher education: theory and practice, $27,16-22$.

\section{Резюме}

Коструба А.В. Педагогічна модель формування професійних компетентностей правника: українські реалії.

Стрімкий розвиток інформаційних технологій призвів до глобальної комп’ютеризації суспільства. Наслідком цього явища у сфері освіти стале формування середовища розробленої обробки даних, модульної побудови інформаційних систем (поєднання різних типів архітектурних рішень у межах одного комплексу). У результаті процес накопичення знань для формування навичок професійних компетентностей поступово змінює форму своєї реалізації. Наведене вимагає актуалізації питання модернізації освітніх процесів у напрямі формування компетентністно-орієнтованого навчання і виховання професійного юриста в світлі його діалогово-дискусійної та лінгвоінтенсівной професійної діяльності, створення відповідної моделі професійної підготовки юриста.

Методологічну основу дослідження складає герменевтичний підхід у педагогіці та ідеї сінергетікі в гуманітарній парадигмі наукового знання, положення діяльнісного підходу в освіті, теоретичні розробки компетентнісного підходу у вищій професійній освіті що дозволило сформувати підхід до навчальних цілей іншого якісного типу, серед яких доцільність формування прикладних професійних правничих навичок, розвиток критичного мислення тощо.

У роботі сформовано алгоритм професійної підготовки майбутнього юриста, який передбачає в якості основного елементу створення моделі формування професійних компетентностей правника через діяльністний підхід.

Педагогічна модель правника грунтується на органічній єдності теоретичної, практичної, психофізичної підготовки, що забезпечує рівень професійної соціалізації. В основі моделі чотири сегмента: цілістний, змістовний, дидактичний і оціночнорезультативний. Дослідження процесу формування професійних компетентностій юриста через встановлену модель дозволило встановити недоліки у змістовному й дидактичному сегментах, які полягають у перевантаженості навчальних програм зайвими дисциплінами гуманітарного змісту і відсутності прикладної складової в навчальному процесі, яка домінувати сьогодні.

Ключові слова: юридична освіта, компетентністний підхід, педагогіка вищої школи, педагогічна дидактика, юридична клініка. 


\section{Резюме}

Коструба А.В. Педагогическая модель формирования профессиональных компетенций юриста: украинские реалии.

Стремительное развитие информационных технологий привело к глобальной компьютеризации общества. Следствием этого явления в сфере образования стало формирование среды обработки данных, модульного построения информационных систем (сочетание различных типов архитектурных решений в рамках одного комплекса). В результате процесс накопления знаний для формирования навыков профессиональных компетенций постепенно меняет форму своей реализации. Приведенное требует актуализации вопроса модернизации образовательных процессов в направлении формирования компетентностноориентированного обучения и воспитания профессионального юриста в свете его диалогово-дискуссионной и лингвоинтенсивной профессиональной деятельности, создание соответствующей модели профессиональной подготовки юриста.

Методологическую основу исследования составляет герменевтический подход в педагогике и идеи синергетики в гуманитарной парадигме научного знания, положения деятельностного подхода в образовании, теоретические разработки компетентностного подхода в высшем профессиональном образовании что позволило сформировать видение учебных целей другого качественного типа, среди которых целесообразность формирования прикладных профессиональных юридических навыков , развитие критического мышления и тому подобное.

В работе сформирован алгоритм профессиональной подготовки будущего юриста, который предусматривает, в качестве основного элемента, создание модели формирования профессиональных компетенций юриста через деятельностный подход.

Педагогическая модель юриста основывается на органическом единстве теоретической, практической, психофизической подготовки, обеспечивает уровень профессиональной социализации. В основе модели четыре сегмента: целостная, содержательный, дидактический и оценочно-результативный. Исследование процесса формирования профессиональной компетентности юриста через установленную модель позволило установить недостатки в содержательном и дидактическом сегментах, которые заключаются в перегруженности учебных программ лишними дисциплинами гуманитарного содержания и отсутствия прикладной составляющей в учебном процессе, которая доминировать сегодня.

Ключевые слова: юридическое образование, компетентностный подход, педагогика высшей школы, педагогическая дидактика, юридическая клиника.

\section{Summary}

Anatolii Kostruba. Pedagogical model of the formation of professional competences of lawyers: Ukrainian reality.

Rapid development of information technologies has led to the global computerization of society. As a result of this phenomenon in the field of education, the developed data processing environment, modular assembly of information systems (combination of different types of architectural solutions within the same complex) were formed. Consequently, the process of knowledge accumulation for the development of professional competence skills gradually changes the form of implementation. Well-known goals of higher education that are discovered in such elements as knowledge, understanding, forms of their gaining are subject to changes. The foregoing calls for the change in the educational paradigm one of the components of which, in our opinion, should be the transition to educational goals of another qualitative type in the cognitive field, including the development of applied professional legal skills, development of critical thinking, etc. This study contains the formed algorithm of professional training of the future lawyer which provides for the production of a model for the formation of professional competences of the lawyer as the basic element. Such a pedagogical model shall be based on the organic unity of theoretical, practical, psychophysical training, which in turn will provide the level of professional socialization. The model is based on four segments: target, meaningful, didactic and evaluation and productive. The study of the process of the formation of professional competences of the lawyer using the established model has made it possible to identify shortcomings in the content and didactic segments, which consist in overload of curricula with unnecessary disciplines of humanitarian content and lack of applied component in the educational process.

Key words: legal education, competent approach, higher education pedagogy, pedagogical didactics, legal clinic.

DOI: $10.36695 / 2219-5521.2 .2020 .05$

УДК 340.115

\section{Л.В. ДЯчУК}

Леонтій Володимирович Дячук, кандидат історичних наук, доцент Київського національного університету імені Тараса Шевченка

\section{BASILICORUM LIBRI: SECUNDAE NUPTIAE**}

Здійснення законодавчих реформ перші імператори Македонської династії (Василій I та Лев VI Філософ) розуміли як відтворення актуальних норм усіх правових інститутів окремих частин Corpus juris civils Юстиніана (Дигести, Кодекс, Інституції, Новели) на мовній основі грецької юридичної лексики, тобто як створення свого роду «грецького Юстиніана» (І. Медведєв). Звичайно, для здійснення такого монументального завдання передбачалось створити масивне юридичне зібрання, поділене на 60 книг, яке отримало назву Basilicorum libri (імператорські книги).

Слід зазначити, що Basilicorum libri, не зважаючи на різні оцінки щодо їх призначення, викликали професійний інтерес як у візантійських юристів X-IV ст., так і в європейських дослідників від середніх віків

(C) Л.В. Дячук, 2020

${ }^{*}$ Leontiy Diachuk, Ph.D. in History, Associate Professor of Taras Shevchenko National University of Kyiv

** Стаття подана в авторській редакції 